\title{
Macroporous polymer supported azide and nanocopper (I): efficient and reusable reagent and catalyst for multicomponent click synthesis of 1,4-disubstituted-1H-1,2,3-triazoles from benzyl halides
}

\author{
Mosadegh Keshavarz ${ }^{1 *}$, Nasir Iravani ${ }^{2}$, Abdolmohammad Ghaedi², Amanollah Zarei Ahmady ${ }^{3}$, \\ Masoumeh Vafaei-Nezhad ${ }^{2}$ and Sara Karimi ${ }^{2}$
}

\begin{abstract}
Macroporous polymer supported nanoparticles of copper(I) iodide catalyst and macroporous polymer supported azide reagent were used to simplify the synthesis of 1,4-disubstituted-1H-1,2,3-triazoles from various benzyl halides following the green chemistry principles. This new one-pot protocol facilitates the workup of the reaction and provides the products in short times and at high yields. Heterogeneous catalyst and reagent can be reloaded and reused at least for 5 runs without significant decrease in the yields.
\end{abstract}

Keywords: Polymer supported catalyst, Sodium azide, Triazole, Click chemistry, Benzyl halide

\section{Background}

Consistent with one of the basic principles of Green Chemistry, catalytic or recyclable reagents are better than stoichiometric reagents (Anastas and Warner 1998). Polymer-supported reagents have more and more attracted attention as insoluble matrices in organic synthesis (Kirschning et al. 2001; Hodge et al. 2005). They recommend rewards such as reaction monitoring as well as improved safety, more than ever when the nonsupported reagents are toxic or unsafe as they can be easily removed from reaction medium and recycled (Galaffu et al. 2005; Erb et al. 2003). Additionally, employing an excess amount of reagent is permitted without the need for further purification.

Sodium azide is vital reagent and copper(I) is a wonderful catalyst for 1,3-dipolar cycloaddition between organic azides and terminal alkynes which is best known as click reaction (Lwowsky 1984; Rostovtsev et al. 2002; Hein et al. 2008). This cycloaddition has been used in

\footnotetext{
* Correspondence: Chem.mosadegh@gmail.com

${ }^{1}$ Department of Chemistry, Yasouj University, P.O. Box 353, 75918-74831,

Yasouj, Iran

Full list of author information is available at the end of the article
}

various ways in drug discovery, chemical biology and medicinal chemistry (Moorhouse et al. 2008; Moorhouse and Moses 2008; Gil MV et al. 2007; Moses and Moorhouse 2007), as well as material science and solid phase organic synthesis (Yao et al. 2008; Wu et al. 2004; Bodine et al. 2004; Lober and Gmeiner 2004). Nevertheless, sodium azide and copper salts are highly toxic compounds. Sodium azide is a potent toxin, has a comparable toxicity as that of cyanide ion $\left(\mathrm{LD}_{50}=27 \mathrm{mgkg}^{-1}\right.$ for rats) and can be absorbed through the skin mucous membranes. The excess amount of sodium azide is wasted during the nucleophilic substitution reaction in organic processes and pollutes the environment since it is not usually recovered from reaction medium.

Despite of toxicity, copper(I) salts have been less used as catalyst for this cyclization in view of the fact that they are thermodynamically instable and the formation of undesired alkyne-alkyne coupling products which is sometimes observed in their existence (Tornøe et al. 2002; Aucagne and Leigh 2006). On the other hand, these homogeneous processes suffer from one or more disadvantages such as difficulty in separation of the product from the reaction medium. These homogenous 
Table 1 Synthesis of 1,4-disubstituted-1H-1,2,3-triazoles using polymer supported reagent and catalyst

\begin{tabular}{llccc}
\hline Entry Benzyl halide (a) & Product (b) & $\begin{array}{c}\text { Time } \\
\text { (h) }\end{array}$ & $\begin{array}{c}\text { Yield } \\
\text { (\%) })^{\mathbf{c}}\end{array}$ & m.p./Lit. m.p ${ }^{\circ} \mathbf{C}$ \\
\hline 1 & 1 & 92 & $128-129 / 128-129.5$ \\
(Shamim and Paul 2010)
\end{tabular}

2<smiles>ClCc1ccccc1</smiles>

3<smiles>Cc1cccc(CBr)c1</smiles>

4<smiles>COc1ccc(CBr)cc1</smiles>

5<smiles>O=[N+]([O-])c1ccc(CBr)cc1</smiles>

6<smiles>Clc1ccc(CBr)c(Cl)c1</smiles>

7<smiles>BrCc1ccc(Br)cc1</smiles>

8<smiles>COc1ccc(CBr)cc1</smiles>

9<smiles>BrCc1ccccc1</smiles>

10<smiles>BrCc1ccccc1</smiles>

11<smiles>ClCc1ccccc1</smiles>

12<smiles>COc1ccc(CBr)cc1</smiles>

13<smiles>c1ccc(Cn2cc(-c3ccccc3)nn2)cc1</smiles><smiles>Cc1cccc(Cn2cc(-c3ccccc3)nn2)c1</smiles><smiles>COc1ccc(Cn2cc(-c3ccccc3)nn2)cc1</smiles><smiles>O=[N+]([O-])c1ccc(Cn2cc(-c3ccccc3)nn2)cc1</smiles><smiles>Clc1ccc(Cn2cc(-c3ccccc3)nn2)c(Cl)c1</smiles><smiles>Brc1ccc(Cn2cc(-c3ccccc3)nn2)cc1</smiles><smiles>COc1ccc(Cn2cc(C(C)O)nn2)cc1</smiles>

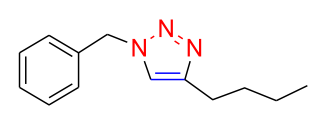<smiles>OCc1cn(Cc2ccccc2)nn1</smiles><smiles>OCc1cn(Cc2ccccc2)nn1</smiles> 
Table 1 Synthesis of 1,4-disubstituted-1H-1,2,3-triazoles using polymer supported reagent and catalyst (Continued)

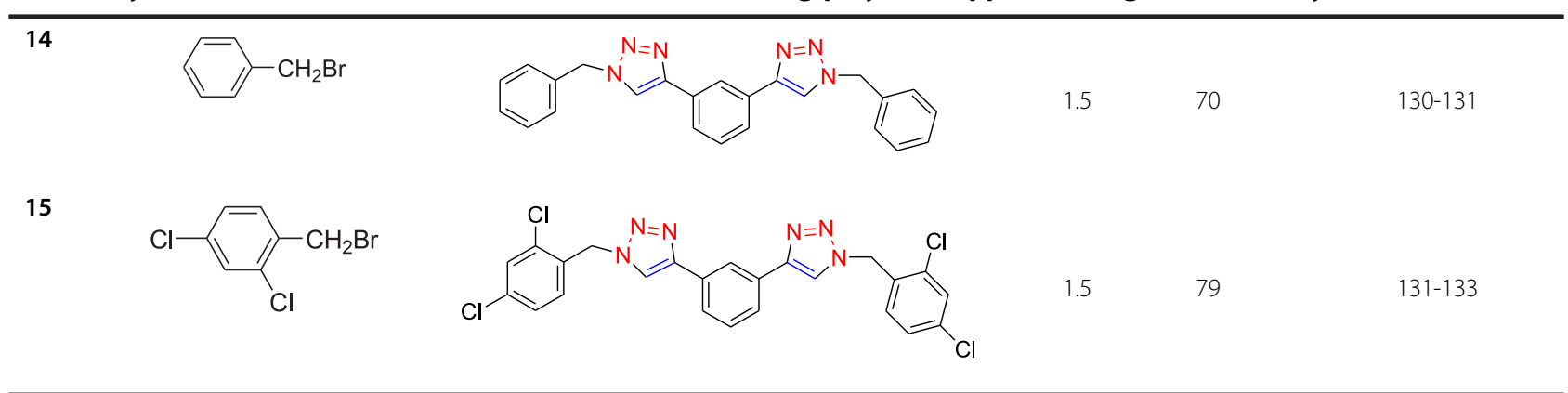

${ }^{c}$ Yields refer to isolated and pure products.

catalysts are usually non-recyclable, have low regioselectivity and long reaction times. However, nitrogen or phosphorus-based ligands have been shown to protect the metal center from oxidation and disproportionation, while enhancing its catalytic activity (Gerard et al. 2006; Marra et al. 2008; Broggi et al. 2008). Recently, heterogeneous copper(I) catalysts based on silica (Miao and Wang 2008; Shamim and Paul 2010), montmorillonite (Jlalia et al. 2008), zeolites (Bénéteau et al. 2010; Chassaing 2010) and $\mathrm{Cu}$ in charcoal (Sharghi et al. 2009) and $\mathrm{Cu}$ nanoporous skeleton catalyst (Jin et al. 2011, 2012; Asao et al. 2012) have been developed. There are also some reports on using polymer supported $\mathrm{CuI}$ as recoverable catalyst for this cyclization (Albadi et al. 2012a, 2012b; Albadi and Keshavarz 2013; Girard et al. 2006; Jlalia et al. 2010; Dervaux and Du Prez 2012).

In recent years, nano-catalysis has emerged as a sustainable and competitive alternative to conventional catalysis since the nanoparticles possess a high surface-to-volume ratio, which enhances their activity and selectivity, while at the same time maintaining the intrinsic features of a heterogeneous catalyst (Astruc 2008). In particular, the immobilization of copper (I) salts nanoparticles on highsurface-area supports allows a higher stability and dispersity of the particles as well as a further exploitation of the special activity and recycling properties of the catalyst. These catalysts possess better advantages than their homogeneous counterparts. However, to the best of our knowledge, there is no report for one-pot multicomponent synthesis of 1,4-disubstituted-1 $H$-1,2,3-triazoles which utilize polymer supported azide which can significantly reduce the toxicity and ecological impacts of this reagent. Herein we report a new, facile and green procedure for on-pot multicomponent click synthesis of 1,4-disubstituted- $1 H-1,2,3-$ triazoles from benzyl halides and terminal alkynes using polymer supported azide and nanoparticles of $\mathrm{CuI}$.

\section{Experimental section}

Materials and methods

All of the triazole derivatives were prepared by our procedure; their spectroscopic and physical data were compared with those of authentic samples. NMR spectra were recorded in DMSO- $\mathrm{d}_{6}$ or $\mathrm{CDCl}_{3}$ on a Bruker Advanced DPX 500 and $400 \mathrm{MHz}$ instrument spectrometers using TMS as internal standard. IR spectra were recorded on a BOMEMMB-Series 1998 FT-IR spectrometer.

Preparation of polymer-supported azide reagent (IRA-910 $\mathrm{N}_{3}$ ) Amberlite IRA-400 $\mathrm{N}_{3}$ form was easily prepared from its corresponding chloride form via ion exchange using $10 \%$ $\mathrm{NaN}_{3}$ aqueous solution. Two grams of amberlite IRA400 chloride form (mesh 16-50) were stirred for $6 \mathrm{~h}$ in the corresponding solution $\left(100 \mathrm{~mL}\right.$ of $10 \% \mathrm{NaN}_{3}$ aqueous solution), filtered-off and washed several times with water and stirred for additional $5 \mathrm{~min}$, it was then decanted, washed several times with water until the supernatant liquid gave a negative azide test with ferric nitrate and dried under vacuum at $50^{\circ} \mathrm{C}$.

The exchange capacity of the resin was determined by passing $1 \mathrm{~N}$ sodium chloride solution $(50 \mathrm{~mL})$ through the resin $(0.3 \mathrm{~g})$ packed in a column. The amount of sodium salt of the nucleophile in the eluent was then titrated with $0.01 \mathrm{~N}$ hydrochloric acid using methyl orange as indicator.

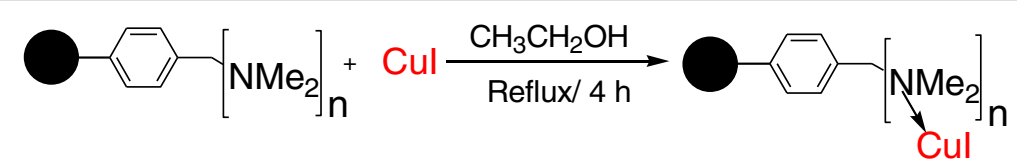

Figure 1 Preparation of Amberlyst supported nanoparticles of Cul (A-21Cul). 


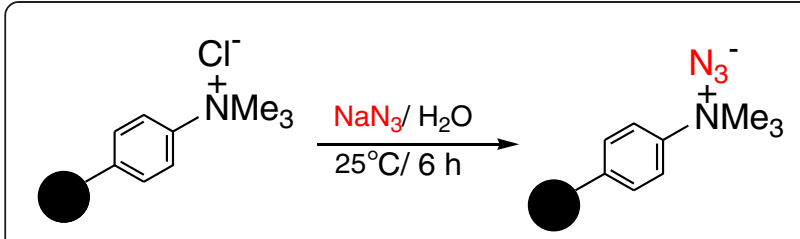

Figure 2 Preparation of amberlite supported azide (IRA-400 $\left.\mathrm{N}_{3}\right)$.

The exchange capacity of polymer supported nucleophile was calculated to be $3.5 \mathrm{mmolg}^{-1}$ of $\mathrm{N}_{3}^{-}$.

\section{Preparation of the supported catalyst (A-21Cul)}

$\mathrm{CuI}(100 \mathrm{mg})$ was dissolved in $30 \mathrm{~mL}$ absolute ethanol, and magnetically stirred in a pre-heated oil bath at reflux temperature for $4 \mathrm{~h}$ under a nitrogen atmosphere in the presence of dry amberlyst $A-21$ (1.0 g, $4.8 \mathrm{mmol}$ amine; mesh 20-50). The resulting materials were washed with ethanol $(4 \times 30 \mathrm{~mL})$ and dried under vacuum at $40^{\circ} \mathrm{C}$ overnight. To evaluate the copper content, the $\mathrm{A} 21-\mathrm{Cu}$ (100 mg) was extracted with concentrated $\mathrm{HCl}(5 \times 2 \mathrm{~mL})$ in a screw-capped vessel, followed by treatment with concentrated nitric acid ( $2 \mathrm{~mL})$ to digest the metal complex. The mixture was then transferred into a volumetric flask $(100 \mathrm{~mL})$, diluted 1:50 for the second time and was analyzed by the ICP analysis. The copper concentration was determined from the atomic emissions $(324.754 \mathrm{~nm})$ by reference to a linear $(\mathrm{R}=0.99)$ calibration curve of (1-4 ppm) CuI prepared in a manner identical to the sample preparation. The copper content of $\mathrm{A21-CuI}$ was calculated to be $11.7 \% \mathrm{w} / \mathrm{w}$.

Typical procedure for multicomponent synthesis of 1-phenyl-2-(4-phenyl-1-H-1,2,3-triazol-1yl)-1-ethanone (Table 1 , entry 1$)$.
Benzyl halide ( $1 \mathrm{mmol}, 2 \mathrm{mmol}$ for entries 13 and 14) and 1,3-diethynylbenzene $(1 \mathrm{mmol})$ were placed together in a round-bottom flask containing $10 \mathrm{~mL}$ of ethanol. Amberlyst $A-21 \mathrm{CuI}(1 \mathrm{mo} \%, 0.03 \mathrm{~g})$ and amberlite $I R A-910 \mathrm{~N}_{3}(0.5 \mathrm{~g}$, loading: $3.5 \mathrm{meqg}^{-1}$ ) were added at once to the mixture. The suspension was magnetically stirred under reflux conditions for appropriate time shown in Table 1. After completion of the reaction as followed by TLC (n-hexane: ethyl acetate; $4: 1$ ), the resins were filtered and washed with hot ethanol $(2 \times 5 \mathrm{~mL})$. The filtrates were evaporated to dryness, and then the solid residue was recrystallized in ethanol/ water $(1: 3 \mathrm{v} / \mathrm{v})$ to give pure product crystals.

\section{Reusing of polymer supported catalyst and reagent}

The filtered mixture of resins was washed with $25 \mathrm{~mL}$ of distillated water and stirred for $6 \mathrm{~h}$ in the corresponding solution (50 mL of $10 \% \mathrm{NaN}_{3}$ aqueous solution) and dried under vacuum at $50^{\circ} \mathrm{C}$ before next run.

\section{Selected spectral data}

1-(4-methoxybenzyl)-4-phenyl-1H-1,2,3-triazole (Table 1, 3b): m.p 128-130; ${ }^{1} \mathrm{H}$ NMR $\left(\mathrm{CDCl}_{3}, 500 \mathrm{MHz}\right) \delta /$ ppm : $7.81(\mathrm{~d}, 2 \mathrm{H}, J=11 \mathrm{~Hz}), 7.71(\mathrm{~s}, 1 \mathrm{H}), 7.40(\mathrm{t}, 2 \mathrm{H}$, $J=8.4 \mathrm{~Hz}), \quad 7.34-7.29(\mathrm{~m}, 2 \mathrm{H}), 6.91-6.84(\mathrm{~m}, 3 \mathrm{H}), 5.53$ (s, 2H), 3.78(s, 3H).

1-(2,4-dichlorobenzyl)-4-phenyl-1H-1,2,3-triazole (Table 1, 5b): m.p 147-149; ${ }^{1} \mathrm{H}$ NMR $\left(\mathrm{CDCl}_{3}, 500 \mathrm{MHz}\right) \delta / \mathrm{ppm}$ : 7.86(d, $2 \mathrm{H}, J=9 \mathrm{~Hz}), 7.8(\mathrm{~s}, 1 \mathrm{H}), 7.52(\mathrm{~d}, 1 \mathrm{H}, J=2 \mathrm{~Hz}), 7.46$ $(\mathrm{t}, 2 \mathrm{H}, J=7.5 \mathrm{~Hz}), 7.38(\mathrm{t}, 1 \mathrm{H}, J=7.5 \mathrm{~Hz}), 7.32-7.30(\mathrm{~m}, 1 \mathrm{H})$, $7.21(\mathrm{~d}, 1 \mathrm{H}, J=8 \mathrm{~Hz}), 5.72(\mathrm{~s}, 2 \mathrm{H})$.

1-(4-bromobenzyl)-4-phenyl-1H-1,2,3-triazole (Table 1, 6b): m.p 152-152.5/151-152; ${ }^{12}{ }^{1} \mathrm{H}$ NMR $\left(\mathrm{CDCl}_{3}\right.$, $400 \mathrm{MHz}) \delta / \mathrm{ppm}: 7.82(\mathrm{~d}, 2 \mathrm{H}, J=7.5 \mathrm{~Hz}), 7.69(\mathrm{~s}, 1 \mathrm{H})$, $7.54(\mathrm{~d}, 2 \mathrm{H}, J=8.3 \mathrm{~Hz}), 7.43(\mathrm{t}, 2 \mathrm{H}, J=7.5 \mathrm{~Hz}), 7.35$ (t, $1 \mathrm{H}, J=7.5 \mathrm{~Hz}), 7.21(\mathrm{~d}, 2 \mathrm{H}, J=8.3 \mathrm{~Hz}), 5.56(\mathrm{~s}, 2 \mathrm{H})$.

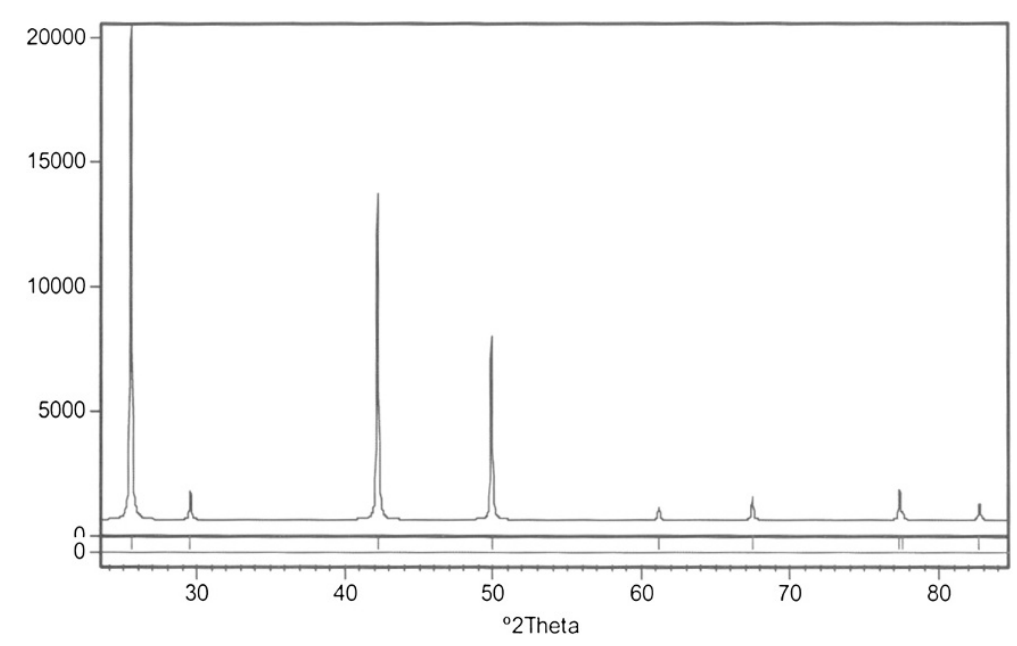

Figure 3 XRD pattern of amberlyst supported Cul. 


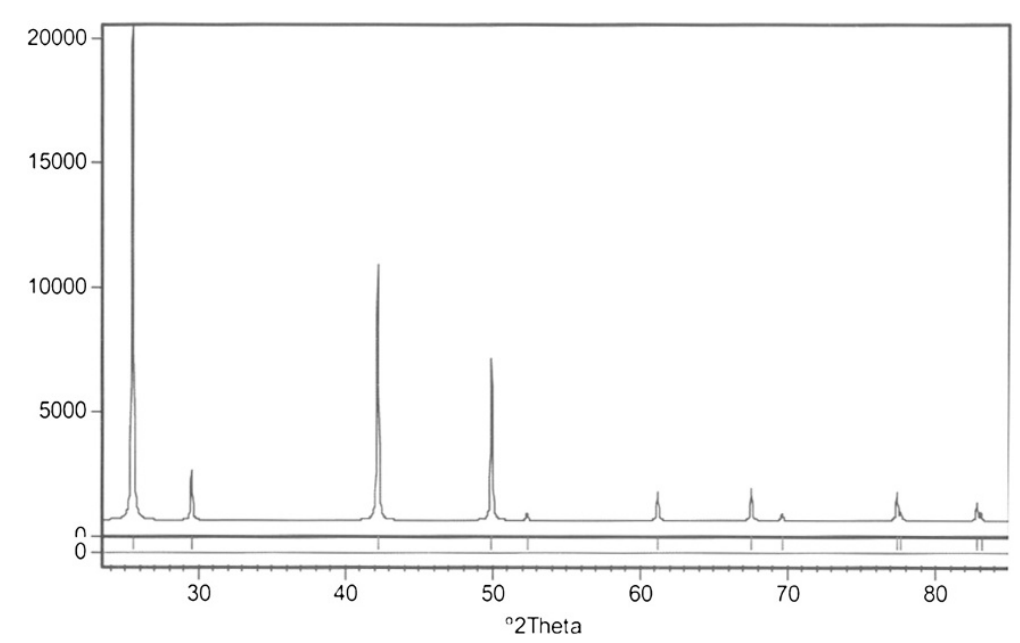

Figure 4 XRD pattern of pure Cul.

3-(1-benzyl-1H-1,2,3-triazole-4-yl)aniline (Table 1, 12b): IR (KBr): 3420 and 3338 $\left(\mathrm{NH}_{2}\right) \mathrm{cm}^{-1},{ }^{1} \mathrm{H}-\mathrm{NMR}(500$ $\left.\mathrm{MHz}, \mathrm{DMSO}-\mathrm{d}_{6}\right): \delta / \mathrm{ppm}: 8.35(\mathrm{~s}, 1 \mathrm{H}), 8.11(\mathrm{~d}, 2 \mathrm{H}$, $J=7.46 \mathrm{~Hz}), 7.75(\mathrm{t}, 1 \mathrm{H}, J=7 \mathrm{~Hz}), 7.63(\mathrm{t}, 2 \mathrm{H}$, $J=7.32 \mathrm{~Hz}), 7.15(\mathrm{~s}, 1 \mathrm{H}), 7.9(\mathrm{t}, 1 \mathrm{H}, J 7.6 \mathrm{~Hz}), 6.98(\mathrm{~d}$, $1 \mathrm{H}, J=7.5 \mathrm{~Hz}), 6.56(\mathrm{~d}, 1 \mathrm{H}, J=7.5 \mathrm{~Hz}), 6.22(\mathrm{~s}, 2 \mathrm{H}), 5.22$ (s, 2H); ${ }^{13} \mathrm{C}$ NMR (125 MHz, DMSO-d 6 ): $\delta / \mathrm{ppm}$ : $149.9,147.85,135.13,135.02,132.09,130.27,129.88$, $129.8,123.46,114.48,113.9,111.38,56.78$.

1-(2,4-dichlorobenzyl)-4-\{3-[1-(2,4-dichlorobenzyl)-1H-1, 2,3-triazole-4-yl]phenyl\}-1H-1,2,3-triazole (Table 1, 14b): m.p 131-133. ${ }^{1} \mathrm{H}$ NMR (DMSO-d $\left.6,400 \mathrm{MHz}\right) \delta / \mathrm{ppm}$ : 8.67(s, 2H), 8.34(s, $1 \mathrm{H}), 7.82(\mathrm{~d}, 2 \mathrm{H}, J=7.7 \mathrm{~Hz}), 7.73(\mathrm{~d}$, $2 \mathrm{H}, J=1.8 \mathrm{~Hz}), 7.51-7.49(\mathrm{~m}, 3 \mathrm{H}), 7.36(\mathrm{~d}, 2 \mathrm{H}, J=8.3 \mathrm{~Hz})$, 5.76(s, 4H); ${ }^{13} \mathrm{C}$ NMR (100 MHz, DMSO-d 6 ) $\delta / \mathrm{ppm}$ : 146.7, 134.5, 134.3, 132.7, 132.5, 131.6, 130, 129.6, 128.4, 125.2, 122.6, 122.3, 50.8.

\section{Results and discussion}

This situation requires the development of a novel polymer-supported heterogeneous catalyst and reagent that can join the advantages of both, homogenous and heterogeneous in order to obtain competent reagent and catalyst. The preparation procedures followed to obtain macroporous polymer supported nanoparticles of $\mathrm{CuI}$ catalyst and polymer supported azide reagent are

Table 2 The effect of solvent on the reaction progress

\begin{tabular}{cccccc}
\hline Entry & Solvent & IRA-400 N $_{\mathbf{3}}$ & A-21Cul & Time (h) & Yield (\%) \\
\hline 1 & $\mathrm{CH}_{2} \mathrm{Cl}_{2}$ & $0.5 \mathrm{~g}$ & $60 \mathrm{mg}$ & 2 & 41 \\
2 & $\mathrm{H}_{2} \mathrm{O}$ & $0.5 \mathrm{~g}$ & $60 \mathrm{mg}$ & 2 & 39 \\
3 & $\mathrm{CH}_{3} \mathrm{CH}_{2} \mathrm{OH}$ & $0.5 \mathrm{~g}$ & $60 \mathrm{mg}$ & 1 & 90 \\
4 & $\mathrm{CH}_{3} \mathrm{CN}$ & $0.5 \mathrm{~g}$ & $60 \mathrm{mg}$ & 1 & 83 \\
\hline
\end{tabular}

${ }^{a}$ Yield refer to pure and separated products. outlined in Figures 1 and 2. These consist of building up suitable heterogeneous polymer supported nanocopper (I) catalyst (Figure 1) and macroporous polymer supported azide nucleophile (Figure 2) structures on the surface of commercial available amberlyst A21 (mesh 2050) and amberlite $I R A-400 C l$ (mesh 16-50). Preparation of heterogeneous copper(I) iodide catalyst and polymer supported azide reagent by these procedures are facile and straightforward.

The nanocopper catalyst immobilized on amberlyst A21 (mesh 20-50) was readily prepared in a one-step procedure. Amberlyst A21 was refluxed with $\mathrm{CuI}$ under an $\mathrm{N}_{2}$ atmosphere in $\mathrm{EtOH}$ to afford the polymer-supported $\mathrm{CuI}$ nanoparticles catalyst. Immobilization of nanoparticles of $\mathrm{CuI}$ on amberlyst support (A21-CuI) was approved by scanning electron microscopy (SEM, see the Additional file 1), IR, X-ray diffraction (XRD) and ICP analysis techniques. The SEM image of the prepared catalyst indicated that $\mathrm{CuI}$ nanoparticles were homogeneously immobilized on amberlyst surface. According to the SEM images of the obtained A21-CuI, the average size of copper nanostructures was estimated to be $75-90 \mathrm{~nm}$. The sharp peaks of copper were observed in the XRD patterns of copper iodide on amberlyst (Figure 3). Their positions were consistent with metallic copper (Figure 4, also see the Additional file 1) and copper iodide nanocrystals and confirmed the presence of copper iodide on the amberlyst surface again. The size of copper nanoparticle was also determined from X-ray line broading using the Debye-Scherrer formula (obtained size: $75 \mathrm{~nm}$ ).

Amberlite IRA-400 $\mathrm{N}_{3}$ form was easily prepared from its related chloride form via ion exchange using $10 \%$ $\mathrm{NaN}_{3}$ aqueous solution. Appearing a signal in $2050 \mathrm{~cm}^{-1}$ region in the IR spectrum of IRA $400 \mathrm{~N}_{3}$ confirmed the presence of azide on the surface on this commercial 


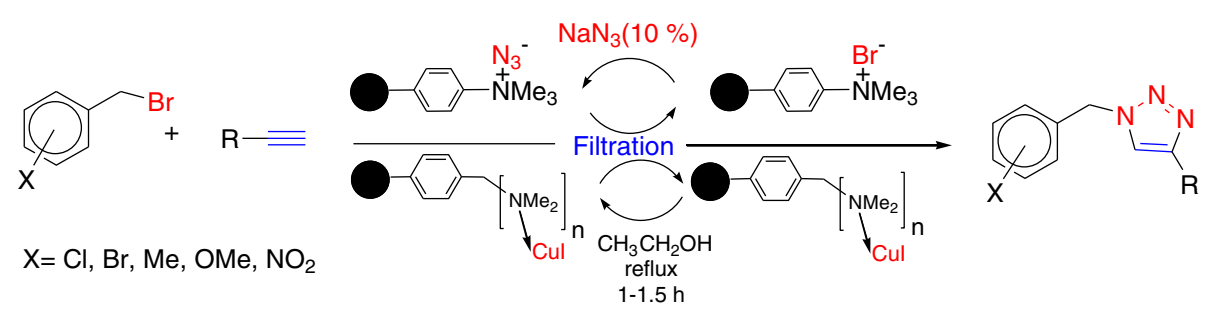

Figure 5 Multicomponent synthesis of 1,4-disubstituted-1H-1,2,3- triazoles using recoverable polymer supported azide and Cul.

available ion exchange polymer. The exchange capacity of the IRA $400 \mathrm{~N}_{3}$ was determined by passing $1 \mathrm{~N}$ sodium chloride solution through the IRA $400 \mathrm{~N}_{3}$ packed in a column. The amount of sodium salt of the nucleophile in the eluent was then titrated with 0.01 normal hydrochloric acid using methyl orange as indicator. The exchange capacity of polymer supported nucleophile was calculated to be $3.5 \mathrm{mmolg}^{-1}$ of $\mathrm{N}_{3}^{-}$.

After preparation of polymer supported catalyst and reagent we began to optimize the reaction conditions. Phenyl acetylene and benzyl bromide were selected as the test substrates and acetonitrile, methylene chloride, ethanol and water as solvents. Unluckily, we did not get good results at room temperature with various amounts of heterogeneous catalyst and reagent with each of solvents after 4 hours. So the reaction was followed at reflux conditions.

From Table 2, ethanol, $A-21 C u I(60 \mathrm{mg}, 10 \%)$ and IRA$400 N_{3}(0.5 \mathrm{~g})$ are optimized conditions for multicomponent click cyclization. The results were evaluated qualitatively through TLC (Table 2). The best conditions employ 1:1:1.5:0.1 mol ratios of phenyl acetylene, benzyl bromide, IRA-400 $\mathrm{N}_{3}$ and $\mathrm{A}-21 \mathrm{CuI}$ at reflux conditions using ethanol as solvent. Using these optimized conditions, the reaction of various terminal alkynes and benzyl bromide was examined (Figure 5).

All the products were cleanly isolated with simple filtration and evaporation of solvent (Table 1). The solid products were easily recrystallized from a mixture of ethanol/water $(1: 3 \mathrm{v} / \mathrm{v})$ or in some cases from ethanol (Table 1, entry 13 and 14). Click condensations were confirmed by the appearance of a singlet in the region of 8-8.5 ppm in ${ }^{1} \mathrm{H}$-NMR spectra, which corresponds to the hydrogen on 5-position of triazole ring and confirms the regioselective synthesis of 1,4-disubstituted triazole regioisomers (Keshavarz and Badri 2011).

Since organic azides are often unstable to heat and light, their in situ preparation recommends a great choice to their use and handling. All benzyl azides were prepared in situ and subjected to multicomponent click cyclization with various terminal alkynes. The using of 1,3-diethynylbenzene in click cyclizations led to the synthesis of some interesting symmetrical bis-triazoles (Table 1, entry 13, 14 and Figure 6).

The recyclability and reusability of the supported catalyst or reagent is important. To investigate this property for our introduced catalyst, the reaction of benzyl bromide with phenyl acetylene was selected again as model (Table 3).

After reaction completion, the resins mixture was washed with distilled water and then subjected to aqueous $\mathrm{NaN}_{3}$ solution to reload IRA-400 $\mathrm{N}_{3}$. This process repeated for five runs and no appreciable yield decrease was observed. Almost consistent activity was observed over five runs (Table 3).

Next we checked the leaching of $\mathrm{CuI}$ nanoparticles into the reaction mixture from the amberlyst support using ICP-AES. The difference between the copper content of the fresh catalyst and the used catalyst (5th run) was only $3 \%$ which indicated the low leaching amount of copper iodide catalyst into the reaction mixture.

The results suggest that the catalyst and reagent developed are maintaining their efficiency in repeated uses. Polymer supported $\mathrm{CuI}$ can be reused up to five runs without need to reload and Polymer supported azide nucleophile can be loaded several times.

Table 4 represents the efficiency of the introduced method in comparison with some of the reported

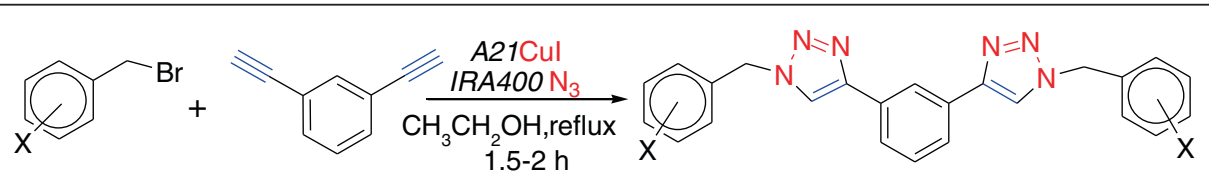

$\mathrm{X}=\mathrm{H}$ or $\mathrm{Cl}$

Figure 6 Synthesis of symmetrical substituted bis-triazoles using 1,3-diethynylbenzene. 
Table 3 Recyclability and reusability of polymer supported azide and Cul

\begin{tabular}{cccccc}
\hline Entry & 1 & 2 & 3 & 4 & 5 \\
Number of loading & 1 & 2 & 3 & 4 & 5 \\
Yield (\%) & 90 & 90 & 89 & 87 & 87 \\
\hline${ }^{a}$ Yields refer to isolated and pure products.
\end{tabular}

${ }^{a}$ Yields refer to isolated and pure products.

methodologies. Although in some previous reports the rate of the reaction is faster than our present method (entries 2, 3 and 4), the superiority of this work is that both catalyst and reagent $\left(\mathrm{N}_{3}^{-}\right)$are recoverable. In is worth to note that the yield of the product by our procedure is comparable with reported methods

\section{Conclusions}

In conclusion, we have developed a simple, benign and multicomponent regioselective synthesis of biologically important 1,4-disubstituted-1H-1,2,3-triazoles with short times in high yields under polymer supported catalyst and reagent conditions. The methodology is conveniently applicable to a wide range of benzyl halides and acetylenic compounds, and permits the assembly of a diverse set of 1,4-disubstituted-1H-1,2,3-triazoles. The final reaction product can be simply filtered and separated without the need for a further chromatographic step. In addition, the spent polymeric reagent can be regenerated and reused several times without appreciable loss in its capacity and efficiency. Using of $A-21 \mathrm{CuI}$ as catalyst protects the metal center from oxidation and disproportionation, while enhancing its catalytic activity and makes it to be a reusable catalyst at least for five runs. Minimal waste generation of this "user-friendly" process should be beneficial for industrial applications.

\section{Table 4 Evaluation of the introduced methodology in comparison with some of the previously reported methods}

\begin{tabular}{|c|c|c|c|c|c|}
\hline Entry & $\begin{array}{l}\text { Reagent/catalyst/ } \\
\text { solvent }\end{array}$ & $t\left({ }^{\circ} \mathrm{C}\right)$ & Time (h) & Yield & Reference \\
\hline 1 & $\begin{array}{c}\mathrm{NaN}_{3} / \mathrm{Silica}^{-} \\
\text {supported } \mathrm{Cu}(\mathrm{l}) / \mathrm{EtOH}\end{array}$ & 78 & $24 \mathrm{~h}$ & 93 & $\begin{array}{l}\text { (Miao and } \\
\text { Wang 2008) }\end{array}$ \\
\hline 2 & $\begin{array}{c}\mathrm{NaN}_{3} / \text { Silica- } \\
\text { supported } \mathrm{Cu}(\mathrm{I}) / \mathrm{H}_{2} \mathrm{O}\end{array}$ & 25 & 0.25 & 91 & $\begin{array}{l}\text { (Shamim and } \\
\text { Paul 2010) }\end{array}$ \\
\hline 3 & $\begin{array}{l}\mathrm{NaN}_{3} / \mathrm{Nano} \mathrm{Cu}(\mathrm{l}) \text { on } \\
\text { Charcol/ } \mathrm{H}_{2} \mathrm{O}\end{array}$ & 100 & 0.6 & 91 & $\begin{array}{l}\text { (Sharghi et al. } \\
\text { 2009) }\end{array}$ \\
\hline 4 & $\begin{array}{c}\mathrm{NaN}_{3} / \mathrm{P}_{4} \mathrm{VPy}-\mathrm{Cul} / \\
\mathrm{H}_{2} \mathrm{O}\end{array}$ & 100 & 0.25 & 90 & $\begin{array}{l}\text { (Albadi et al. } \\
\text { 2012b) }\end{array}$ \\
\hline 5 & $\begin{array}{c}\mathrm{NaN}_{3} / \mathrm{Cul} / \mathrm{i}-\mathrm{Pr}_{2} \mathrm{EtN} \\
\text { (additive) } /\left[\mathrm{C}_{8} \text { dabco }\right] \\
{\left[\mathrm{N}(\mathrm{CN})_{2}\right]}\end{array}$ & 25 & 16 & 95 & $\begin{array}{c}\text { (Marra et al. } \\
\text { 2008) }\end{array}$ \\
\hline 6 & $\begin{array}{c}\text { IRA-400 N3/ A-21Cul/ } \\
\mathrm{CH}_{3} \mathrm{CH}_{2} \mathrm{OH}\end{array}$ & 80 & 1 & 92 & (This work) \\
\hline
\end{tabular}

\section{Additional file}

Additional file 1: SEM image of Amberlyst supported nanoparticles of Cul. XRD spectrum of Amberlyst supported nanoparticles of Cul.

IR spectrum of amberlite supported azide $\left(I R A-400 \mathrm{~N}_{3}\right)$.

\section{Competing interests}

The authors declare that they have no competing interests.

\section{Authors' contributions}

MK designed the study and wrote the manuscript, SK and MVN performed experiments; NI and ABG collected and analyzed data; AZA provided reagents, supplies and technical support. All authors read and approved the final manuscript.

\section{Authors' information}

Dr. Mosadegh Keshavarz: He was born in 1980 in Dehdasht, Iran. He received a B.Sc. degree of pure chemistry from the Teacher Training University of Tehran and after studying for three years at the Shahid Chamran University of Ahvaz, he obtained a M.Sc. degree in Organic Chemistry under the supervision of Professor Rashid Badri. He received his Ph.D. degree of organic chemistry from Chamran University in 2012 and is currently working as assistant professor at Yasouj University.

Dr. Nasir Iravani: He finished his B.Sc and M.Sc degrees in Organic Chemistry from Islamic Azad University of Chachsaran. He received his Ph.D. of Organic Chemistry from Science and Research Campus, Islamic Azad University, Ponak, Tehran at 2010 and is currently working at Islamic Azad University of Gachsaran.

Dr. Amanollah Zarei Ahmady: He finished his B.Sc, M.Sc and Ph.D. degrees in Organic Chemistry from Shahid Chamran University of Ahvaz. He is currently working as assistant researcher in the Medicinal Herbs and Natural Compounds researches Center, Jondi Shapour University of Ahvaz. Dr. Abdolmohammad Ghaedi: He finished his B.Sc degree of pure Chemistry from Shiraz University. He received his M.Sc degree in Applied Chemistry from Kermanshah University and his Ph.D. of Applied chemistry from Science and Research Campus, Islamic Azad University, Ponak, Tehran at 2011 and is currently working at Islamic Azad University of Gachsaran.

Miss Masoumeh Vafaeen-nezhad: She received her B.Sc degree of Chemistry degree of Pure Chemisry from Shahid Chamran University and her M.Sc degree of Organic Chemistry from Islamic Azad University of Gachsaran. She is continuing her Ph.D. theses at Islamic Azad University of Arak. Miss Sara Karimi: She received her B.Sc degree of Chemistry degree of Applied Chemistry from Islamic Azad University of Gachsaran. She is continuing her M.Sc degree of Organic Chemistry at Persian Gulf University.

\section{Acknowledgment}

We are grateful to the Research Council of Yasouj University and Islamic Azad University, Gachsaran Branch for financial support.

\section{Author details}

'Department of Chemistry, Yasouj University, P.O. Box 353, 75918-74831, Yasouj, Iran. ${ }^{2}$ Department of Chemistry, Gachsaran branch, Islamic Azad University, Gachsaran, Iran. ${ }^{3}$ Nanotechnology Research Center, Faculty of Pharmacy, Jundishapur University of Medical Sciences, Ahvaz, Iran.

Received: 5 November 2012 Accepted: 13 February 2013

Published: 23 February 2013

\section{References}

Albadi J, Keshavarz M (2013) Polymer supported azide and cupper(I): green reusable reagent and catalyst for click cyclization. Synth Commun 43:1

Albadi J, Keshavarz M, Shirini F, Vafaei-nezhad M (2012a) Copper iodide nanoparticles on poly(4-vinyl pyridine): A new and efficient catalyst for multicomponent click synthesis of 1,4-disubstituted-1,2,3-triazoles in water. Catal Commun 27:17

Albadi J, Keshavarz M, Abedini M, Vafaei-nezhad M (2012b) Copper iodide nanoparticles on poly(4-vinyl pyridine) as new and green catalyst for multicomponent click synthesis of 1,4-disubstituted-1,2,3-triazoles in water. Chin Chem Lett 23:797 
Anastas PT, Warner JC (1998) Environmental chemistry; environmental management; industrial applications. Green Chemistry: Theory and Practice. Oxford Universit Press Inc, New York

Asao N, Jin T, Tanaka S, Yamamoto V (2012) Molecular Catalysts to Nanostructured Materials Skeleton Catalysts. Pure and Appl Chem 84:1771

Astruc D (2008) Nanoparticles and Catalysis. Wiley-VCH Verlag GmbH \& Co. KGaA, Weinheim

Aucagne V, Leigh DA (2006) Chemoselective formation of successive triazole linkages in One Pot: "Click - Click" chemistry. Org Lett 8:4505

Bénéteau V, Olmosa A, Boningari T, Sommer J, Pale P (2010) Zeo-click synthesis: Cul-zeolite-catalyzed one-pot two-step synthesis of triazoles from halides and related compounds. Tetrahedron Lett 51:3673

Bodine KD, Gin DY, Gin MS (2004) Synthesis of readily modifiable cyclodextrin analogues via cyclodimerization of an alkynyl - azido trisaccharide. J Am Chem Soc 126:1638

Broggi J, González SD, Petersen JL, Raboin SB, Nolan SP, Agrofoglio LA (2008) Study of copper(I) catalysts for the synthesis of carbanucleosides via azidealkyne 1,3-dipolar cycloadditio. Synthesis 1:141

Chassaing S, Alix A, Boningari T, Sido KSS, Keller M, Kuhn P, Louis B, Sommer J, Pale P (2010) Copper(I)-zeolites as new heterogeneous and green catalysts for organic synthesis. Synthesis 1557

Dervaux B, Du Prez FE (2012) Heterogeneous azide-alkyne click chemistry: towards metal-free end products. Chem Sci 3:959-966

Erb B, Kucma JP, Mourey S, Struber F (2003) Polymer-supported triazenes as smart reagents for the alkylation of carboxylic acids. Chem Eur J 9:2582

Galaffu N, Sechi G, Bradly M (2005) Polymer resin library and the discovery of highly efficient polymer supported reagents and scavengers. Mol Divers 9:263

Gerard B, Ryan J, Beeler AB, Porco JA (2006) Synthesis of 1,4,5-trisubstituted-1,2,3triazoles by copper-catalyzed cycloaddition-coupling of azides and terminal alkynes. Tetrahedron 62:6405

Gil MV, Arevalo M, Lopez JO (2007) Click chemistry - what's in a name? Triazole synthesis and beyond. Synthesis 11:1589

Girard C, Onen E, Aufort M, Beauviere S, Samson E, Herscovici J (2006) Reusable polymer-supported catalyst for the [3+2] Huisgen cycloaddition in automation protocols. Org Lett 8:1689-1692

Hein CD, Liu X, Wang MD (2008) Click chemistry, a powerful tool for pharmaceutical sciences. Pharm Res 25:2216

Hodge P (2005) Synthesis of organic compounds using polymer-supported reagents, catalysts, and/or scavengers in benchtop flow systems. Ind Eng Chem Res 44:8542

Jin T, Yan M, Menggenbateer, Minato T, Bao M, Yamamoto Y (2011) Nanoporous Copper Metal Catalyst in Click Chemistry: Nanoporosity-Dependent Activity without Supports and Bases. Adv Synth Catal 353:3095

Jin T, Yan M, Yamamoto V (2012) Click Chemistry of Alkyne-Azide Cycloaddition Using Nanostructured Copper Catalysts. Chem Cat Chem 4:1217

Jlalia I, Elamari H, Meganem F, Herscovici J, Girarad C (2008) Copper(I)-doped Wyoming's montmorillonite for the synthesis of disubstituted 1,2,3-triazoles. Tetrahedron Lett 49:6756

Jlalia I, Beauvineau C, Beauviere S, Onen E, Aufort M, Beauvineau A, Khaba E, Herscovici J, Meganem F, Girard C (2010) Automated synthesis of a 96 product-sized library of triazole derivatives using a solid phase supported copper catalyst. Molecules 15:3087-3120

Keshavarz M, Badri R (2011) A facile and one pot synthesis of 1,4-disubstituted$1 \mathrm{H}-1,2,3$-triazoles from terminal alkynes and phenacyl azides prepared from styrenes by CAN oxidant and sodium azide. Mol Divers 15:957

Kirschning A, Monenschein H, Wittenberg R (2001) Functionalized polymers Emerging Versatile Tools for Solution-Phase Chemistry and Automated Parallel Synthesis. Angew Chem Int Ed 40:650

Lober S, Gmeiner P (2004) Click chemistry on solid support: synthesis of a new REM resin and application for the preparation of tertiary amines. Tetrahedron 60:8699

Lwowsky W (1984) 1,3-dipolar cycloaddition chemistry. vol 1, Chap. 4. Wiley-Interscience, New York, p 621

Marra A, Vecchi A, Chiappe C, Melai B, Dondoni A (2008) Validation of the copper (I)-catalyzed azide - alkyne coupling in ionic liquids. Synthesis of a triazolelinked C-disaccharide as a case study. J Org Chem 73:2458

Miao T, Wang $L$ (2008) Regioselective synthesis of 1,2,3-triazoles by use of a silicasupported copper $(I)$ catalyst. Synthesis 3:363

Moorhouse AD, Moses JE (2008) Click Chemistry and Medicinal Chemistry: A Case of "Cyclo-Addiction". Chem Med Chem 3:715
Moorhouse AD, Haider Gunaratnam SM, Munnur D, Neidle S, Moses JE (2008) Targeting telomerase and telomeres: a click chemistry approach towards highly selective G-quadruplex ligands. Mol Biosyst 4:629

Moses JE, Moorhouse AD (2007) The growing applications of click chemistry. Chem Soc Rev 36:1249

Rostovtsev W, Green LG, Fokin W, Sharpless KB (2002) A stepwise Huisgen cycloaddition process: Copper(l)-catalyzed regioselective ligation of azides and terminal alkynes. Angew Chem Int Ed 41:2596

Shamim T, Paul S (2010) Silica Functionalized Cu(I) as a green and recyclable heterogeneous catalyst for the Huisgen 1,3-dipolar cycloaddition in water at room temperature. Catal Lett 136:260

Sharghi H, Khalifeh R, Doroodmand MM (2009) Copper nanoparticles on charcoal for multicomponent catalytic synthesis of 1,2,3-triazole derivatives from benzyl halides or alkyl halides, terminal alkynes and sodium azide in water as a "Green" solvent. Adv Synth Catal 351:207

Tornøe CW, Christensen C, Meldal M (2002) Peptidotriazoles on solid phase: [1,2,3]-triazoles by regiospecific copper(I)-catalyzed 1,3-dipolar cycloadditions of terminal alkynes to azides. J Org Chem 67:3057

Wu P, Sharpless B, Fokin W (2004) Efficiency and fidelity in a click-chemistry route to triazole dendrimers by the copper $(I)$-catalyzed ligation of azides and alkynes. Angew Chem Int Ed 43:3928

Yao RX, Kong LZ, Yin S, Qing FL (2008) Synthesis of novel aromatic ether polymers containing perfluorocyclobutyl and triazole units via click chemistry. J Fluorine Chem 129:1003

\section{doi:10.1186/2193-1801-2-64}

Cite this article as: Keshavarz et al:: Macroporous polymer supported azide and nanocopper (I): efficient and reusable reagent and catalyst for multicomponent click synthesis of 1,4-disubstituted-1 $\mathrm{H}$-1,2,3-triazoles from benzyl halides. SpringerPlus 2013 2:64.

\section{Submit your manuscript to a SpringerOpen ${ }^{\circ}$ journal and benefit from:}

- Convenient online submission

- Rigorous peer review

- Immediate publication on acceptance

- Open access: articles freely available online

- High visibility within the field

- Retaining the copyright to your article

Submit your next manuscript at springeropen.com 